\title{
A Method for the Determination of the Electrophoretic Patterns of Hemolyzed Mouse Sera ${ }^{1}$
}

\author{
Marie H. Berg and Pauline R. Mole \\ From the Department of Dermatology and Syphilology, University of Michigan \\ Medical School, Ann Arbor, Michigan
}

Received October 6, 1950

\section{INTRODUCTION}

In electrophoretic studies on pooled mouse sera (1) from white Swiss mice bred at the Ann Arbor University Hospital, it was found very difficult to avoid a considerable amount of hemolysis. Since this hemolysis varied from one specimen to another and could easily be avoided in other breeds of mice, no comparable results could be obtained in the electrophoretic serum pattern. Patterns obtained by Moore and co-workers (2) in a"series of electrophoretic studies of human serum in veronal buffer have shown that hemolysis creates an increase in the $\beta$-boundary. They have shown that added amounts of hemoglobin, as measured photometrically, would not give a proportional increase. Stern and Reiner (3) have shown in their electrophoretic analyses of material from hemolyzed cells of different species that the products of hemolysis do not move in the electric field as one boundary only, but that there are two distinct components: a small " $a$ " boundary with a mobility of $6 \times 10^{-5}$, and the hemoglobin with a mobility of $3 \times 10^{-5}$ $\mathrm{cm}^{2} / \mathrm{sec}$./volt, in veronal buffer $\mathrm{pH} 8.6,0.1 \mathrm{M}$. Furthermore, Reiner and Moore (4) have demonstrated that globin separated from hemoglobin will give two boundaries in the electrophoretic analysis. Also, Dognon and Gougerot (5) suggest the nonhomogeneity of human hemoglobin.

In general, in our mouse sera the hemoglobin caused an asymmetrical $\beta$-peak with an average mobility of $2.8 \times 10^{-5} \mathrm{~cm} .{ }^{2} / \mathrm{sec} . / \mathrm{volt}$ in veronal

${ }^{1}$ These studies were made possible by the Harry Helfman Pemphigus Research Fund. Presented at the 118th Meeting of the American Chemical Society Division of Biological Chemistry. 
buffer $\mathrm{pH} 8.6,0.1 M$ (temperature $4^{\circ} \mathrm{C}$.). However, with amounts of hemoglobin higher than 0.5 g. $\%$ there can be indications of a subdivided $\beta$-peak, which will not separate properly on prolonged electrophoresis (Fig. 1). Besides the $\beta$-peak, hemolyzed mouse sera produce a much smaller peak (the " $a$ " boundary), that moves in front of the albumin and has an average mobility of $6.5 \times 10^{-5} \mathrm{~cm} .{ }^{2} / \mathrm{sec} . /$ volt. This peak varies irregularly and may sometimes be absent entirely. This " $a$ "

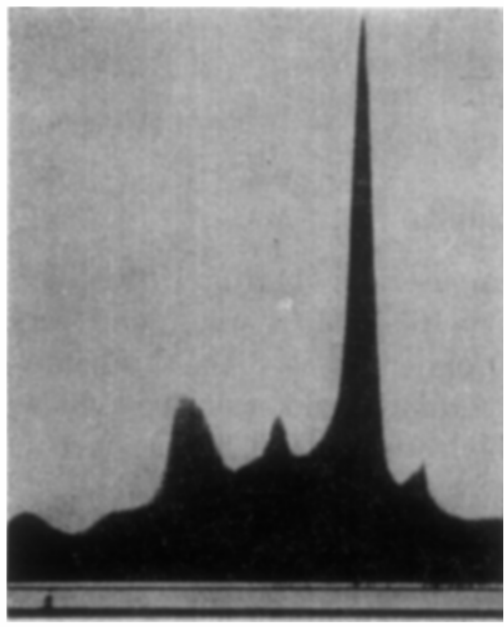

(a)

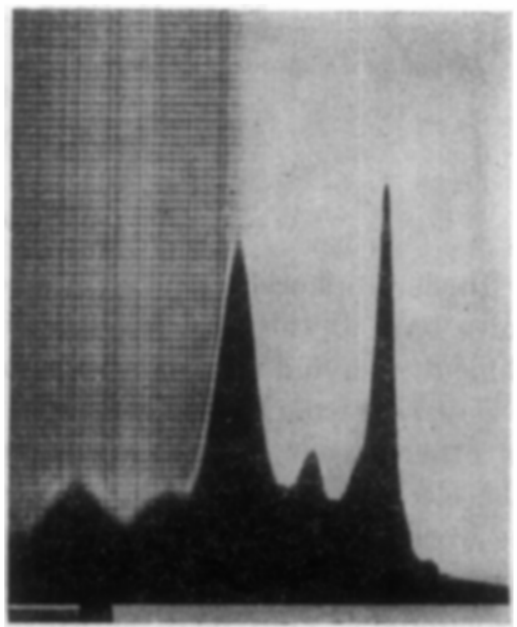

(b)

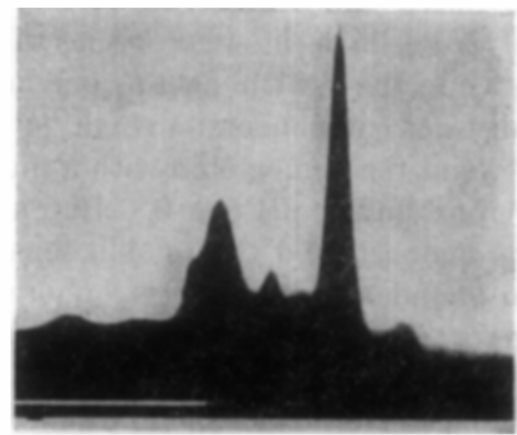

(e)

FrG. 1. Electrophoretic patterns of hemolyzed mouse sera: (a) Descending pattern, 0.5 g. $-\%$ hemoglobin protein. (b) Ascending pattern, 1.7 g.- $\%$ hemoglobin protein. (c) Descending pattern, 0.7 g. $\%$ hemoglobin protein, subdivided peak. 
boundary originates from the stroma of the red cells. It is a protein, just as is the globin of the hemoglobin, and its amount has to be determined before corrections of the serum pattern can be made.

\section{MeTHODS}

White Swiss mice were put under ether anesthesia, bled from the heart, and the pooled blood was allowed to clot. The serum was separated from the clot by centrifuging $20 \mathrm{~min}$. at 3200 r.p.m. The serum was then placed into the refrigerator immediately, and the clot was broken up under $0.85 \%$ saline and filtered through one layer of cheesecloth, yielding a suspension of red cells. These red cells were washed three times with $0.85 \%$ saline, centrifuged, and the supernatant fluid was discarded each time. The cells were then put into a $-15^{\circ} \mathrm{C}$. refrigerator overnight, and the following day were broken up by thawing. Three to five dilutions with $0.85 \%$ sodium chloride solution were made with this thawed cell-hemoglobin suspension. These dilutions were then centrifuged for the same period of time and at the same speed as were the original mouse sera. In the original serum as well as in the hemoglobin solutions the hemoglobin was determined by the oxyhemoglobin method (6); the total proteins were determined by the biuret method (7).

\section{Results}

The values of the hemoglobin in the dilutions were plotted as abscissas against those of the corresponding total protein as ordinates on arithmetic-scale graph paper. These reference curves yielded a straight line; however, they differed slightly from one mouse blood sample to another. Therefore, this procedure had to be repeated with each new serum sample. Since time also has an influence on the hemoglobin to total protein ratio, determinations for the reference curve had to be made at the same time as determinations for the unknown. The total protein value corresponding to the hemoglobin in the serum could then be found from the reference curve. Immediately after the determinations, the serum was diluted with veronal buffer $(\mathrm{pH} \mathrm{8.6,0.1M})$ and dialyzed for 2 days against the same buffer. Electrophoresis was performed in a Klett-Tiselius apparatus at a temperature of $4^{\circ} \mathrm{C}$. using a 120-v., 100-w. tungsten lamp as a source of light, which together with a Wratten filter minimizes the effect of hemoglobin color. The patterns obtained by scanning photography were evaluated as follows (Table I):

(a) The percentages of the total pattern were calculated: e.g., " $a$ " boundary, albumin, $\alpha$-, $\beta$-, and $\gamma$-globulin.

(b) The percentage of hemolysis protein was calculated in relation to the total protein of the serum. 
(c) From the hemolysis protein percentage in $(b)$, the percentage of " $a$ " area was subtracted, and the remaining percentage should account for the hemoglobin in the $\beta$-boundary.

(d) This calculated amount of hemoglobin in the $\beta$-boundary was deducted from the percentage of $\beta$-globulin in the pattern.

(e) The final values for the albumin, $\alpha$-, $\beta$-, and $\gamma$-globin are then to be computed on a $100 \%$ basis $(A)$.

\section{TABLE I}

Evaluation of Patterns

\begin{tabular}{l|c|c|c|c|c}
\hline \hline & & & \multicolumn{3}{|c}{ Globulins } \\
& (a) & Albumin & \multicolumn{3}{|c}{} \\
\cline { 4 - 6 } & & & $\alpha-$ & $\beta-$ & $\gamma-$ \\
\hline & $\%$ & $\%$ & $\%$ & $\%$ & $\%$ \\
Ascending & 3.94 & 57.48 & 9.45 & 23.62 & 5.51 \\
Descending & 4.24 & 60.17 & 11.86 & 20.34 & 3.39 \\
\hline
\end{tabular}

(b) Total protein: $\quad 5.4 \mathrm{~g} .-\%$.

Hemoglobin-protein: 0.32 g. $-\%=5.9 \%$.

(c) Per cent hemoglobin protein minus per cent " $a$ " = per cent hemoglobin in

Ascending $5.90-3.94$

Descending $\quad 5.90-4.24$

$\beta$-boundary:

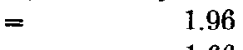

$=\quad 1.66$

(d) Remainino P-gobulin, \%

Ascending 21.66

Remaining total protein, \%

Descending 18.68

94.10

94.10

(e) $\frac{\text { Albumin, } \% \times 100}{94.10}=$ final albumin $\frac{\text { Globulin, } \% \times 100}{94.10}=$ final globulin Results

\begin{tabular}{|c|c|c|c|c|c|}
\hline \multirow{2}{*}{ (A) } & \multirow{2}{*}{ Albumin } & \multicolumn{3}{|c|}{ Globulin } & \multirow{2}{*}{ A/G rati } \\
\hline & & $\alpha-$ & $\beta-$ & $\gamma-$ & \\
\hline Ascending & $\begin{array}{c}\% \\
61.08\end{array}$ & $\begin{array}{c}\% \\
10.04\end{array}$ & $\begin{array}{c}\% \\
23.02\end{array}$ & $\begin{array}{c}\% \\
5.86\end{array}$ & 1.57 \\
\hline Descending & 63.94 & 12.60 & 19.86 & 3.60 & 1.77 \\
\hline \multicolumn{6}{|l|}{ (B) } \\
\hline Ascending & 55.77 & 11.15 & 23.52 & 9.56 & 1.26 \\
\hline Descending & 63.55 & 12.51 & 20.08 & 3.85 & 1.74 \\
\hline
\end{tabular}


We attempted to verify this method by adding supernatant fluid of hemolyzed red cells to sera in order to obtain different hemoglobin concentrations in aliquot samples of the same serum. The values obtained in this manner correlated very well with our calculations in the descending pattern (Table I $B$ ) (total protein 5.55 g.- $\%$, hemoglobin protein, $9.7 \%$ ).

To prove further the validity of this method we took a solution of red cells in saline which was subjected to three repeated freezing and thawing procedures, and then centrifuged for $45 \mathrm{~min}$. to remove all cell membranes. From this hemoglobin we added a known amount to a given quantity of bovine albumin, diluted with veronal buffer $(\mathrm{pH} 8.6$, $0.1 M)$, and performed an electrophoresis experiment exactly in the same manner described before. The patterns are shown in Fig. 2. No

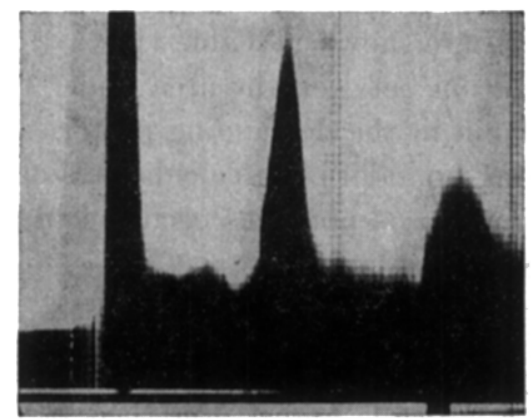

(a)

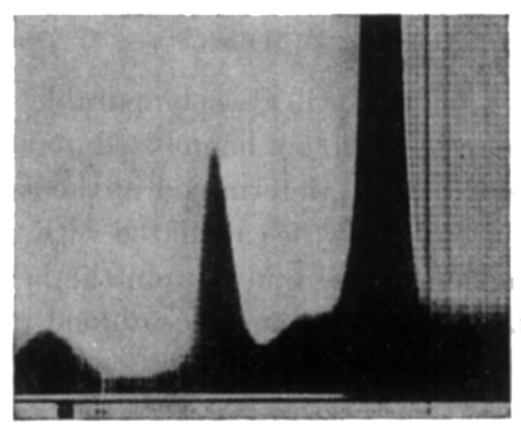

(b)

FiG. 2. Electrophoretic pattern of mixture of bovine albumin and hemoglobin.

(a) Ascending. (b) Descending. 


\section{TABLE II}

\section{Data for Fig. 2 Patterns}

Albumin added: $\quad 5.90$ g.- $\%$ Total protein determined: $\quad 7.10 \mathrm{~g} .-\%$ Hemoglobin added: 1.40 g.- $\%$ Hemoglobin protein determined: $1.23 \mathrm{~g} .-\%$ (From reference curve)

\begin{tabular}{lccc} 
& \multicolumn{2}{c}{ Hemoglobin protein $=17.3 \%$} & \\
& Albumin & $\alpha$-Globulin & Hemoglobin \\
$\%$ & $\%$ & 12.20 & 27.64 \\
Ascending & 60.16 & 6.52 & 17.39 \\
Descending & 76.09 & &
\end{tabular}

" $a$ " boundary could be detected with an albumin boundary of a mobility of $4.7 \times 10^{-5} \mathrm{~cm} .^{2} / \mathrm{sec}$. $/$ volt, a small amount of $\alpha$-boundary at 3.5 $\times 10^{-5} \mathrm{~cm} .{ }^{2} / \mathrm{sec} . /$ volt, or a hemoglobin houndary with a speed of 2.5 $\times 10^{-5} \mathrm{~cm} .{ }^{2} / \mathrm{sec} . /$ volt .

The data obtained are shown in Table II.

There is a correlation belween the area under the $\beta$-curve and the amount of hemoglobin in the descending pattern only. Therefore, we used only descending boundaries in calculations of protein concentrations, especially since no $\beta$-anomalies occurred in any of our 44 electrophoretic mouse sera patterns.

\section{ACKNOWLEDGMENTS}

We wish to thank Dr. Arthur C. Curtis, Chairman of the Department of Dermatology, and Dr. Walter J. Nungester, Professor of Bacteriology, for their kind assistance.

\section{SUMMaRY}

A method is presented that will give comparable results for the evaluation of electrophoretic data on hemolyzed mouse serum patterns. Not only may hemoglobin be determined in the serum, but its contribution to the total protein may be calculated with the aid of a reference curve derived from the data obtained from the hemolyzed red cells of mice taken from the corresponding mouse blood pool.

\section{References}

1. Berg, M. H., and Cuntrs, A. C. Electrophoretic studies in bullous diseases. $J$. Investigative Dermatol., in press. 
2. Moore, D. H., Roberts, J. B., Costello, M., and Schonbegrer, T. W., $J$. Biol. Chem. 1801147 (1949).

3. Stern, K. G., Reiner, M., and Silber, R. H., J. Biol. Chem. 161, 731 (1945).

4. Reiner, L., Moore, D. H., Lang, E. H., and Green, M., J. Biol. Chem. 146, 583 (1942).

5. Dognon, A., And Gougerot, L., Compt. rend. soc. biol. 412, 1490 (1948).

6. Clinical Methods for the Coleman Jr. Spectrophotometer.

7. Weichselbaum, T. E., Am. J. Clin. Path. 10, 40 (1946). 